\title{
The influence of managerial competency and job satisfaction on the performance of teachers of negatiary schools
}

\author{
Sri Wati ${ }^{1}$, Happy Fitria ${ }^{2}$, Syaiful Eddy ${ }^{2}$ \\ ${ }^{1}$ Sekolah Dasar Negeri Bandar Tenggulang, Indonesia \\ ${ }^{2}$ Universitas PGRI Palembang, Indonesia
}

\section{Article Info \\ Article history: \\ Received Jul $13^{\text {th }}, 2021$ \\ Revised Aug $18^{\text {th }}, 2021$ \\ Accepted Aug $30^{\text {th }}, 2021$ \\ Keyword: \\ Managerial competence \\ Job satisfaction \\ Teacher performance}

\begin{abstract}
PT)
This study aims to determine the effect of managerial competence and job satisfaction together on teacher performance. The location of this research was carried out in SD Negeri all Babat Supat District, Musi Banyuasin Regency. This type of research is a quantitative study with a determination design using an ex post facto research design. The sample in this study was the total of all teachers in SD Negeri in Babat Supat District, Musi Banyuasin Regency, consisting of 174 teachers. data collection techniques using a questionnaire. The data analysis technique used quantitative descriptive analysis techniques and multiple regression. The results of this study indicate that 1) there is a significant influence between managerial competence on the performance of public elementary school teachers in Babat Supat District, Musi Banyuasin Regency; 2) there is a significant influence between job satisfaction on the performance of SD Negeri teachers in Babat Supat District, Musi Banyuasin Regency; 3 ) there is a significant effect jointly between managerial competence and job satisfaction on the performance of SD Negeri teachers in Babat Supat District, Musi Banyuasin Regency.
\end{abstract}

(C) 2021 The Authors. Published by IICET.

This is an open access article under the CC BY-NC-SA license (https://creativecommons.org/licenses/by-nc-sa/4.0

\section{Corresponding Author:}

Wati, S.

Sekolah Dasar Negeri Bandar Tenggulang, Indonesia

Email: watisri519@gmail.com

\section{Introduction}

Managerial competence is one of the competencies that principals must possess. The principal managerial competence is the principal's ability to mobilize, direct, guide, protect, set an example, encourage and provide assistance to teachers in a school so that they can be maximally utilized to achieve the goals set by the school [1].

Managerial managerial competence is one of the determining factors in the sustainability and development of educational organizations. To achieve school goals, this is not an easy job to do, because the effectiveness of a leader is measured by the performance and growth of the organization he leads and teacher satisfaction with his leadership [1].

The explanation above is supported by the research results of [1] which show the following: 1) the managerial ability of the principal which consists of aspects of planning, organizing, evaluating and leadership in a good category with an average score of $3.03 ; 2$ ) teacher performance consisting of aspects of preparation, process, and learning assessment in good category with an average score of $3.35 ; 3$ ) the influence of the principal's managerial ability on teacher performance, shows that the managerial ability factor provides an 
effective contribution of 0.591 , which means that $59 \%$ of teacher performance is influenced by the managerial ability of the principal. It can also be interpreted that $41 \%$ is the influence of unexamined variables such as the ability of teachers to develop their professionalism, the availability of supporting facilities needed in the learning process, moral and material support from school leaders.

This research was conducted in Public Elementary Schools in Babat Supat District. Based on the results of observations related to the performance of SD Negeri teachers in Babat Supat District. It is known that the performance of SD Negeri teachers in Babat Supat District has not been maximized based on the results of the 2018 performance report, which states that the performance of teachers in the Disdikporapar of Musi Banyuasin Regency is still low where only $47 \%$ of the total number of teachers have low performance and $19 \%$ of the number of teachers who have been enrolled. certification shows low performance.

In addition, based on the results of observations by researchers in several elementary schools in Babat Supat District from February 10 to February 15, 2020, the researcher stated that teacher performance indicators were still not optimal. Among other things, the teacher's ability to use learning media is still low, so that the quality of the learning process is low and less meaningful for students. This shows that teachers are more oriented towards achieving material targets and are more pursuing high score targets at the National Examination, so they tend to ignore the quality of the learning process. Teachers in carrying out the learning process have a tendency to provide abstract, non-creative and innovative learning, the implementation of less varied assessments tends to be monotonous and have not carried out process assessments.

Then, from the results of the researchers' preliminary observations regarding teacher job satisfaction, it is still visible, especially teachers who are still honorary status. Some regional honorary teachers who have served for a long time, including those who serve up to 9 years with a wage of Rp. 300,000.00, per month or quarter and still survive with unclear employment status. Researchers assess this can be a source of low teacher job satisfaction which greatly affects work productivity. [2] that a teacher who is satisfied with his job will work productively. The above statement is supported by the results of research conducted [3] which states that partially the principal's managerial competence, job satisfaction has a positive and significant effect on teacher performance, while compensation has a negative and insignificant effect on teacher performance in SMK Private sector in Batam City, Riau Islands Province, but simultaneously managerial competence, compensation and job satisfaction have a positive and significant effect on teacher performance in private vocational schools in Batam City, Riau Islands Province.

\section{Method}

This type of research is quantitative research. Quantitative research is a research approach that is often demanded to reveal numbers, starting from data collection, interpretation of the data, and the appearance of the results [4]. This research method uses the partial correlation method, partial correlation is used for analysis or hypothesis testing if the researcher intends to know the influence or relationship between the independent and dependent variables, where one of the independent variables is controlled (made fixed) [5].

Data collection techniques in this study using a questionnaire or questionnaire. [6], a questionnaire or questionnaire is a data collection method that is carried out by giving a set of statements or written statements to respondents to respond according to user requests. The data scale used is the Likert scale. If there are difficulties in understanding the questionnaire, respondents can directly ask the researcher. This questionnaire is used to obtain data on all research variables.

\section{Results and Discussions}

\section{The Effect of Managerial Competence on the Performance of Public Elementary School Teachers in Babat Supat District}

The relationship model of managerial competence on teacher performance is expressed in the form of the regression equation $\mathrm{Y}=4.165+0.489 \mathrm{X} 1$. The regression equation significance test can be presented in the table 1.

Managerial competence on the performance of public elementary school teachers in Babat Supat subdistrict obtained a $t$ value of 5.992> from the t table price of 1.652 where the $t$ value is greater than $t$ table, so Hol is rejected, so there is a significant influence between managerial competence on elementary school teacher performance Negeri in Babat Supat District. The correlation coefficient value between managerial competence and the performance of SD Negeri teachers in Babat Supat District. 


\begin{tabular}{|c|c|c|c|c|c|c|}
\hline \multicolumn{7}{|c|}{ Coefficients $^{\mathrm{a}}$} \\
\hline \multirow{2}{*}{\multicolumn{2}{|c|}{ Model }} & Unstanda & Coefficients & $\begin{array}{l}\text { Standardized } \\
\text { Coefficients }\end{array}$ & & \\
\hline & & B & Std. Error & Beta & $\mathrm{t}$ & Sig. \\
\hline 1 & (Constant) & 4.165 & 1.607 & & 2.591 & .011 \\
\hline & $\begin{array}{l}\text { Managerial } \\
\text { competence }\end{array}$ & .489 & .082 & .507 & 5.992 & .000 \\
\hline & Job satisfaction & .471 & .085 & .470 & 5.559 & .000 \\
\hline
\end{tabular}

a. Dependent Variable: Teacher Performance

The Effect of Job Satisfaction on the Performance of Public Elementary School Teachers in Babat Supat District

The model of the relationship between school work satisfaction and teacher performance is expressed in the form of the regression equation $\mathrm{Y}=4.165+0.471$. $\mathrm{X} 2$ The regression equation significance test can be presented in the following table.

Coefficients $^{\mathrm{a}}$

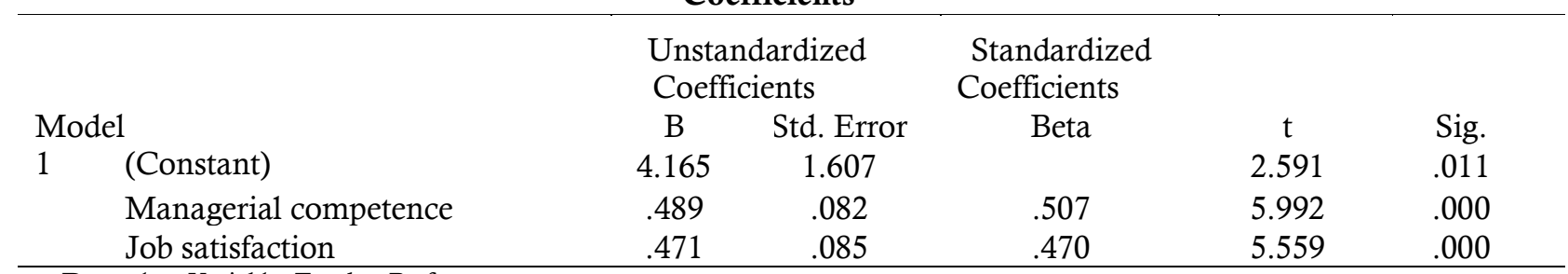

a. Dependent Variable: Teacher Performance

Based on the significance test of the job satisfaction variable on the performance of public elementary school teachers in Babat Supat District, the $t$ value is $5.559 \geq$ the $t$ table price of 1.652 where the $t$ value is greater than the $t$ table, so Ho2 is rejected, so there is a significant influence between job satisfaction and performance. Public SD teachers in all Subdistricts job satisfaction with the performance of Public SD teachers in Babat Supat District.

The Joint Effect of Managerial Competence and Job Satisfaction on the Performance of Public Elementary School Teachers in Babat Supat District

The relationship model jointly managerial competence and job satisfaction on the performance of public elementary school teachers in Babat Supat district is expressed in the form of the regression equation $\mathrm{Y}=$ $4.165+0.489 \mathrm{X} 1+0.471 \mathrm{X} 2$ This means that teacher performance has increased positively through managerial competence and job satisfaction.

To find out the truth of hypothesis testing, a simulation test was carried out using the $\mathrm{F}$ test to determine the effect of managerial competence variables and job satisfaction on teacher performance variables. The testing criteria are as follows.

a. If the probability value (significant) $<0.005$, then $\mathrm{Ho} 3$ is rejected

b. If the probability value (significant) $>0.005$, then $\mathrm{Ho} 3$ is accepted

Then for the F test, the test criteria are as follows.

$\mathrm{Ha} 4$ is accepted if Fcount $>$ Ftable

$\mathrm{H} 04$ is accepted if Fcount $\leq$ Ftable.

\begin{tabular}{llccccc}
\multicolumn{7}{c}{ ANOVA $^{\mathrm{a}}$} \\
\hline Model & & Sum of Squares & Df & Mean Square & F & Sig. \\
\hline 1 & Regression & 11474.190 & 2 & 5737.095 & 1174.990 & $.000^{\mathrm{b}}$ \\
& Residual & 712.870 & 146 & 4.883 & & \\
& Total & 12187.060 & 148 & & & \\
\hline
\end{tabular}

a. Dependent Variable: Teacher Performance

b. Predictors: (Constant), Job satisfaction, Managerial competence

The results of multiple regression analysis can be seen in the following table. Based on the significance test of the variable managerial competence and job satisfaction on the performance of public elementary school 
teachers in Babat Supat District, it is obtained that the F count is 1174,990 with a significance level of 0.000 $<$ probability value $\alpha 0.05$ while $\mathrm{F}$ table is in accordance with The significance level is 0.05 (2.191) of 3.04 so that $\mathrm{F}$ count $>\mathrm{F}$ table $(1174.990>3.04)$ so that Ho3 is rejected, meaning that there is a significant influence jointly between managerial competence and job satisfaction on the performance of public elementary school teachers. se District of Babat Supat.

To find out how much influence the independent variable has on the dependent variable, it can be seen simultaneously in the following summary model table .

\begin{tabular}{lcccc}
\multicolumn{4}{c}{ Model Summary } \\
\hline Model & $R$ & $R$ Square & Adjusted $R$ Square & Std. Error of the Estimate \\
1 & $.970^{\text {a }}$ & .942 & .941 & 2.210 \\
\hline
\end{tabular}

a. Predictors: (Constant), Variabel X2, X1

The table above shows the $\mathrm{R}$ squere value of 0.942 , thus the coefficient of termination is $94.2 \%$ so that it can be concluded that the large influence of managerial competence and job satisfaction on the performance of public elementary school teachers in Babat Supat District is $94.2 \%$ and the remaining, $8 \%$ was influenced by other factors not examined in this study.

\section{Descriptive Statistical Analysis}

The results of statistical descriptive analysis show that managerial competence with very good categories is 0 or $0 \%$, good categories are 80 or $53.69 \%$, good enough categories are 32 or $21.47 \%$, the poor category is 17 or $11.41 \%$, and very less category of 20 or $13.43 \%$. The results of the analysis indicate that managerial competence is in the good category. Then the results of the statistical description analysis of job satisfaction with very good categories amounted to 0 or $0 \%$, both categories amounted to 78 or $52.35 \%$, good enough categories were 32 or $21.48 \%$, the less category was 17 or $11.41 \%$, and very good categories less by 22 or $14.76 \%$. The results of the analysis indicate that the job satisfaction of public elementary schools in Babat Supat District is in a good category. The teacher performance in the very good category amounted to 0 or $0 \%$, the good category was 80 or $53.70 \%$, the good enough category was 38 or $25.50 \%$, the poor category was 12 or $8.05 \%$, and the very poor category was 19 or $12.75 \%$. The results of the analysis indicate that the teacher's performance is in good category. This means that there is a relationship between managerial competence, job satisfaction and teacher performance, where managerial competence and job satisfaction are in good condition, the teacher's performance is also in good condition. Teacher performance is an important element in efforts to improve the quality of education. Therefore, there must be efforts from all elements, both the principal and the teachers themselves in improving the quality of their work.

\section{Hypothesis Test 1}

The results of the simple regression test, obtained the $t$ value of 5.992> from the t table price of 1.652 where the $\mathrm{t}$ value is greater than the $\mathrm{t}$ table, so Hol is rejected, so that there is a significant influence between managerial competence on the performance of SD Negeri teachers in Babat Supat District. Based on the results of statistical tests, the $\mathrm{R}$ value or the correlation coefficient value is 0.734 . This value can be interpreted that the relationship between the two variables is in the strong category. Through this table also obtained the value of $\mathrm{R}$ Square or the coefficient of determination obtained is $61.5 \%$ which can be interpreted that the managerial competency variable has a contribution of $61.5 \%$ to the teacher performance variable. This means that managerial competence has a positive and significant effect on the teacher performance of SD Ngeri Se, Babat Supat District, Musi Banyuasin Regency. [7] which states that there is a significant influence between principal leadership on teacher performance.

Thus it can be seen that the better the managerial competence, the better the teacher's performance. Vice versa, the less good the managerial competence in school management, the less the teacher's performance will be. The results of the verification analysis show that a) managerial competence affects teacher performance; b) Professional competence affects teacher performance; c) Leadership and professional competence of teachers together have an effect on teacher performance. Conclusion, both partially and jointly managerial competence and teacher professional competence affect teacher performance.

3. Hypothesis Test 2

The results of the significance test of the job satisfaction variable on the performance of public elementary school teachers in Babat Supat District obtained the $t$ value of $5.559 \geq$ the t table price of 1.652 where the $t$ value is greater than the table, so $\mathrm{Ho} 2$ is rejected, so there is a significant influence between job satisfaction and performance. Public Elementary School teachers in Babat Supat District. Based on the 
results of statistical tests, the $\mathrm{R}$ value or the correlation coefficient value is 0.711 . This value can be interpreted that the relationship between the two variables is in the strong category. Through this table also obtained the value of R Square or the coefficient of determination obtained is $57.3 \%$ which can be interpreted that the job satisfaction variable has a contribution of $57.3 \%$ to the teacher performance variable. This means that job satisfaction has a positive and significant effect on teacher performance at SD Ngeri Se, Babat Supat District, Musi Banyuasin Regency in accordance with the opinion of Hasibuan \& Moedjiono (2011: 40) that one of the factors affecting teacher performance in carrying out teaching tasks is teacher behavior. Teacher behavior factors determine the success process.

As the results of research [8] with research results showing that: 1) there is a significant effect of work motivation on teacher performance, 2) there is a significant effect of work discipline on teacher performance, 3) there is a significant influence between motivation work and work discipline on teacher performance.

\section{Hypothesis Test 3}

Anova test results, obtained $\mathrm{F}$ count of 1174,990 with a significance level of $0.000<$ probability value $\alpha 0.05$ while $\mathrm{F}$ table corresponds to a significance level of 0.05 (2.191) of 3.04 so that $\mathrm{F}$ count $>\mathrm{F}$ table $(1174.990>$ 3.04 ) so that $\mathrm{Ho} 3$ is rejected, meaning that there is a significant influence jointly between managerial competence and job satisfaction on the performance of SD Negeri teachers in Babat Supat District. Based on the value of $\mathrm{R}$ squere of 0.942 , thus the coefficient of termination is $94.2 \%$, so it can be concluded that the influence of managerial competence and job satisfaction on the performance of public elementary school teachers in Babat Supat District together is $94.2 \%$ and the remaining is $6.8 . \%$ influenced by other factors not examined in this study.

\section{Conclusions}

Based on the results of the research and discussion, it can be concluded as follows: 1) There is a significant influence between managerial competence on the performance of SD Negeri teachers in Babat Supat District, 2) There is a significant influence between job satisfaction on the performance of SD teachers in Babat Supat District, 3 ) There is a significant effect jointly between managerial competence and job satisfaction on the performance of SD Negeri teachers in Babat Supat District.

\section{References}

[1] Faisal, A. A. (2013). The Influence of Principal's Managerial Ability on the Performance of Public Elementary School Teachers in Kotagede Yogyakarta District. Hanata Widya.

[2] Usop, A. M., Askandar, D. K., Langguyuan, K, M., \& Usop, D. A. S. O. (2013). Work performance and job satisfaction among teachers. International journal of humanities and social science, 3 (5), 245-252.

[3] Yunita, E. (2018). The Effect of Principal Managerial Competence, Compensation and Job Satisfaction on Teacher Performance at Private Junior High Schools in Batam City. Coopetition, 9 (1), 31-42.

[4] Arikunto, S. (2010). Research Procedure. Jakarta: Rineka Cipta

[5] Sugiyono. (2012). Quantitative Research Methods and R and D, Bandung: Alfabeta. $\backslash$

[6] Widoyoko, E, P. (2012). Technique for Developing Research Instruments. Yogyakarta: Student Library.

[7] Damayani, T., Arafat, Y., \& Eddy, S. (2020). The Effect of Principal Leadership and Work Motivation on Performance. Journal of Innovation in Teaching and Instructional Media, 1 (1), 46-57.

[8] Alhusaini, A., Kristiawan, M., \& Eddy, S. (2020). The Effect of Work Motivation and Work Discipline on Teacher Performance. Tambusai Education Journal, 4 (3), 2166-2172.

[9] Simanjuntak, J. M. (2021). The Impact of Principal Leadership on The Effectiveness of Learning in Christian Senior High School in Bandung, Indonesia. Kelola: Jurnal Manajemen Pendidikan, 8(1), 11-21.

[10]Zubaidah, R. A., Haryono, S., \& Udin, U. (2021). The Effects of Principal Leadership and Teacher Competence on Teacher Performance: The Role of Work Motivation. Quality-Access to Success, 22(180). 